\title{
An adaptable and dynamic management strategy for the treatment of polluted mine water from the abandoned Wheal Jane Mine, Cornwall, UK
}

\author{
L.M. Wyatt The Coal Authority, UK
}

I.A. Watson The Coal Authority, UK

S. Kershaw The Coal Authority, UK

A.M.L. Moorhouse The Coal Authority, UK

\begin{abstract}
Following the closure of Wheal Jane Mine in 1991, the mine water was allowed to recover and flood the mine workings. In 1992 a release of contaminated, acidic metal-rich (i.e., $\mathrm{Fe}, \mathrm{Zn}, \mathrm{As}, \mathrm{Mn}, \mathrm{Al}, \mathrm{Cu}, \mathrm{Cr}$ and $\mathrm{Cd}$ ) mine water discharged into the River Carnon; in turn, this flowed into the Fal Estuary, causing a large, visual plume within the estuary at Falmouth. After this pollution incident, the National Rivers Authority (later part of the Environment Agency) established a temporary treatment plant and initiated the process of developing a long-term treatment plant. In 2000, the current active mine water pumping and treatment plant was completed, and operations started to remove the contaminants through chemical (lime) dosing using a series of treatment tanks. Prior to April 2011, this operational aspect of the plant was managed, under contract, by the Environment Agency.
\end{abstract}

Since its inception in 1994, the Coal Authority has constructed and currently operates over 60 mine water remedial schemes for treating contaminated coal mine water. In 2011 the Authority was granted permission to take on work regarding non-coal types of mine water, which led to its managing the Wheal Jane Scheme on behalf of the Environment Agency. The knowledge and expertise at the Coal Authority allowed for a much needed assessment of the existing pumping and treatment regimes at the plant in addition to investigating the wider mining catchment as a whole. The main focus of this assessment was to identify any cost savings and efficiencies, thereby making continuous improvements to the scheme and gaining additional wider knowledge for the site.

To date, since 2011 the Coal Authority and Veolia Water have implemented changes resulting in lime savings of $7 \%$ and polymer savings of $30 \%$ whilst continuing to meet all environmental consents. In addition to this, the Authority has undertaken an appraisal of the geochemistry of the water and begun a regional monitoring network of shaft water levels within the catchment to aid understanding and enable future possible scenarios for the plant to be assessed. Currently the Authority envisages a future in which changes in the mine water pumping regime could result in pumping less water and, in the long term, the establishment of a passive treatment scheme. This would ultimately reduce the financial burden of both active treatment and pumping. The Wheal Jane mine site sits within a larger catchment, which in part is drained by the Great County Adit. The discharge from the County Adit also flows in to the River Carnon, causing additional environmental issues. Together with the scheme at Wheal Jane, the investigations undertaken by the Coal Authority could also see some improvements being made to metal contamination originating from the County Adit.

\section{Introduction}

Wheal Jane mine, located within the Carnon Valley, Cornwall, southwest England (Figure 1), is a former tin mine, with workings dating from at least the early eighteenth century until 1991, when the mine was closed 
and abandoned. Following cessation of de-watering pumping for the mine, water levels rose in the workings. In 1991, the National Rivers Authority (now part of the Environment Agency) recognised the potential for a major pollution outbreak (Hamilton, 1993). Thus, in November 1991 a contingency plan was implemented to control the contaminated mine water at surface (Hamilton, 1993). In January 1992, however, a number of problems occurred, leading to the plan being suspended and the water being built up underground. The Jane adit at the lowest elevation had been blocked, thus there was some uncertainty about where the water could emerge. On 13 January 1992, the water started discharging from a higher adit, releasing approximately $40,000 \mathrm{~m}^{3}$ of contaminated mine water over a few hours with an iron concentration of about $1,800 \mathrm{mg} / \mathrm{L}$, causing discolouration of approximately $50 \mathrm{~km}^{2}$ of the Fal Estuary (Hamilton, 1993). Emergency pumping and treatment were then undertaken from Wheal Jane, carried out by the mine owners. In the following years, remedial options for managing the mine water were considered, with a pilot passive treatment scheme being constructed in 1994, to carry out research into possible long-term solutions. In 2000, an active (chemical treatment) system was constructed and became operational; this treatment scheme is still in use and continues to be fed by water pumped from the shaft.

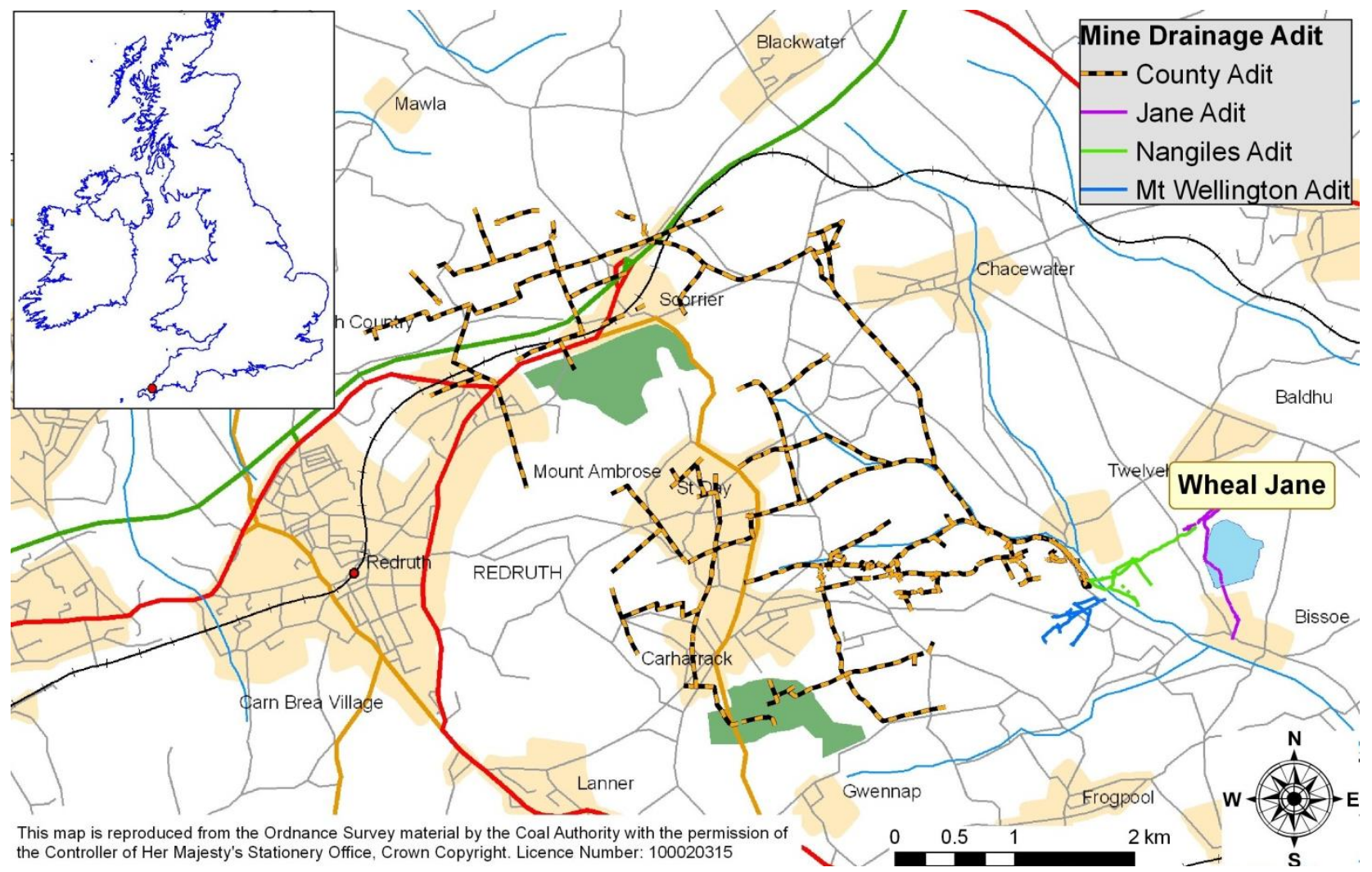

\section{Figure 1 Location map for Wheal Jane and the County Adit catchment area}

The active treatment system is described in detail in a number of other papers (i.e., Coulton et al., 2003; CL:AIRE, 2004). In summary, a high-density sludge approach was implemented, including aeration, neutralisation (by lime dosing) and clarifying (including polymer dosing). The scheme was designed with a capacity of $440 \mathrm{~L} / \mathrm{s}$ and a discharge consent of $350 \mathrm{~L} / \mathrm{s}$ for the treated water into a tributary of the River Carnon. These consents have since been revised to an abstraction rate of $440 \mathrm{~L} / \mathrm{s}$ and a discharge consent of $460 \mathrm{~L} / \mathrm{s}$, which includes the discharge from the toe drain of the tailings lagoon.

\section{$2 \quad$ Mining setting}

Wheal Jane mine is situated towards the southeast section of a network of interconnected abandoned mines, mine workings and drainage adit systems. Wheal Jane Mine (and its workings) is connected to at least three drainage adits: the Jane Adit, Nangiles Adit and the County Adit (or Great County Adit). Although the County Adit was separated from Wheal Jane by a small dam (uncertain level), it is believed that this did 
give way; although it was recommended (c. 1990s) that this should have been replaced, it is unknown if this was done. Wheal Jane is directly connected to Mount Wellington Mine, which in turn connects to other mines via branches of the County Adit. Wheal Jane is also connected to the shallow mine workings of East Wheal Jane (Figure 2). Thus to properly assess Wheal Jane, the entire catchment area of the County Adit must be considered (Figure 1).

The mining catchment incorporates a number of streams and rivers which in places cross areas of lodes, drainage adits and old mine workings. This results in significant 'leakage' of surface water into the mining and associated drainage system. Streams (and valleys) from which infiltration into the mine workings occurs (after Watermeyer, Legge, Piesold \& Uhlmann, 1980) include the Wheal Maid, Poldice and Carnon watercourses; Watermeyer, Legge, Piesold \& Uhlmann (1980) estimated 260 to $270 \mathrm{~L} / \mathrm{s}$ of water was infiltrating from the surface in to the Wheal Jane Mine.

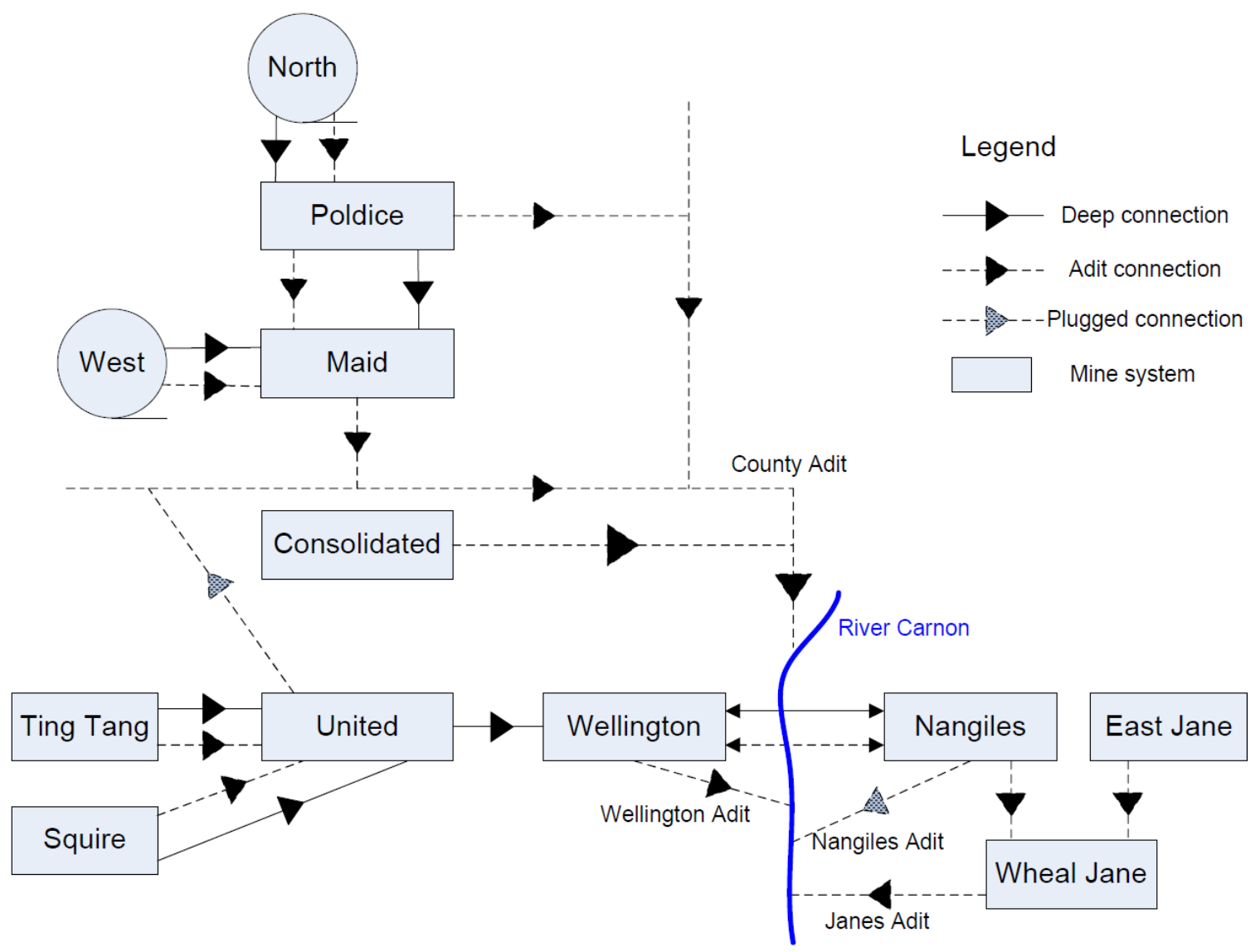

Figure 2 Diagram of mining connections (after Marcus Hodges Environmental Ltd, 1991); note that currently Janes Adit is plugged, whereas Nangiles is not plugged

\section{Management of Wheal Jane scheme, 2000 to 2011}

After the active treatment scheme became operational in 2000, the Environment Agency managed the plant at Wheal Jane. The primary aim and function of the scheme was to pump the mine water in order to prevent uncontrolled surface discharge, combined with treating the pumped polluted mine water, ensuring the discharge consents were not breached.

During the earlier years of pumping, the mine water levels had a wider pumping control band compared with the present day; this was to allow for fluctuations in abstraction relating to seasonal and rainfall changes. However, during this time the chemistry, in response to the changing water levels, also varied greatly (Figure 3). This impacts the treatment needs and in particular the quantity of chemical used, thus 
increasing the scheme costs. Figure 3 also shows a decrease with time of the iron and zinc concentrations. This is a continuation of the long-term exponential decay curve illustrated in Figure 4.

Since 2000, the only monitoring data obtained were those related directly to the control of the mine water at Wheal Jane (i.e., water level and abstraction data), the mine water chemistry, treatment performance and other requirements for operating the plant (e.g., dosing rates). Throughout this time period (20002011), there was no regional monitoring of mine water or other assessments such as shaft sampling or appraisals of new data and/or different treatment options.

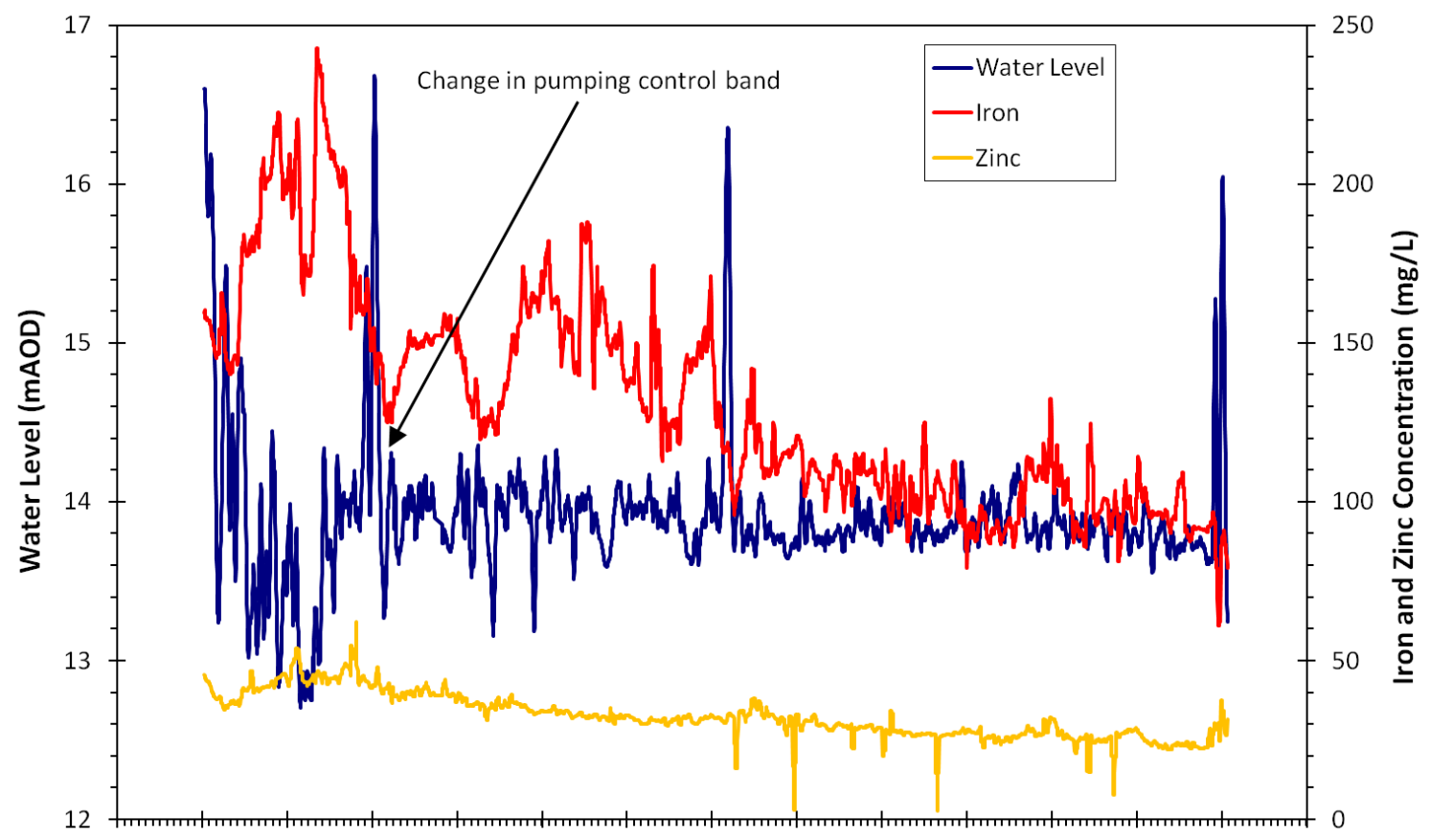

Jan-00 Jan-01 Jan-02 Jan-03 Jan-04 Jan-05 Jan-06 Jan-07 Jan-08 Jan-09 Jan-10 Jan-11 Jan-12 Jan-13 Jan-14

Date

Figure 3 Trends of water level and of iron and zinc for Wheal Jane raw mine water

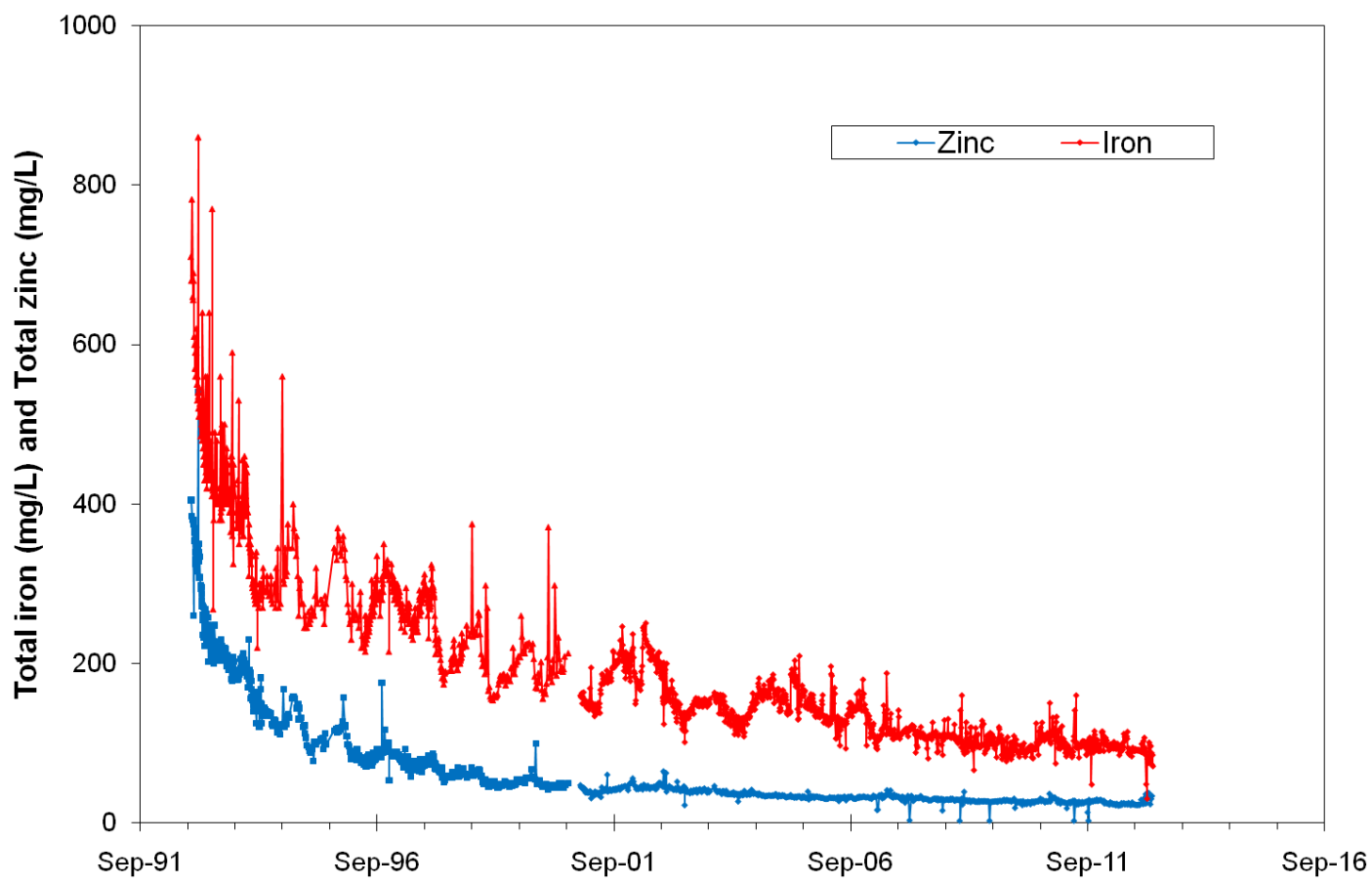

Figure 4 Trend of iron and zinc concentration for Wheal Jane raw mine water 


\subsection{Wheal Jane pilot passive treatment scheme}

Prior to the construction of the current active treatment plant at Wheal Jane in 2000, a temporary active treatment system was built by the Environment Agency in response to the outbreak of contaminated water into the Fal Estuary in January 1992. In conjunction with this earlier active scheme, a pilot passive treatment system was also constructed. This scheme consisted of three trial systems consisting of aerobic wetlands, anaerobic beds and aerobic rock filters in addition to three different pre-treatment methodologies applied to the raw water. The first of these pre-treatments involved using an anoxic limestone drain that was preceded by an anoxic cell containing manure to remove oxygen. The second pre-treatment system used lime dosing to raise the $\mathrm{pH}$ 5.5. The third system was the control, where no pre-treatment was applied to the raw water (i.e., Younger, 2000; Hallberg and Johnson, 2003). The pilot passive scheme was designed to treat 0.1-0.6 L/s (Brown et al., 2002) of mine water from Wheal Jane and successfully reduced influent concentrations of $141 \mathrm{mg} / \mathrm{L}$ iron and $79 \mathrm{mg} / \mathrm{L}$ zinc (Younger, 2000) down to effluent concentrations of $19 \mathrm{mg} / \mathrm{L}$ iron and $45 \mathrm{mg} / \mathrm{L}$ zinc (Younger, 2000). In addition to removing significant concentrations of iron and zinc from the mine water, the pilot passive scheme was also designed to encourage the removal of cadmium, arsenic, copper and manganese (e.g., Hallberg and Johnson, 2003; Whitehead and Prior, 2005). However, Younger (2002) highlights that, with hindsight, the pilot passive scheme was essentially 'back-to-front', in that the acid-generating aerobic cells were upstream of the anaerobic alkalinity generating processes.

\section{$4 \quad$ Management of Wheal Jane scheme post 2011}

In April 2011 the Coal Authority took over management of the Wheal Jane treatment plant. This coincided with the start of a new 10-year contract to operate and maintain the plant, with one of the key drivers being to make rolling efficiency savings of $3 \%$ per annum. The Authority hope to bring its knowledge and experience in managing mine water throughout the UK in order to develop a better understanding of the pumping operations, the hydro-geochemistry, the regional mine water context and any future alternative methods and options for improving the scheme and the environment. Although previous reviews have been done relating to Wheal Jane (i.e., Knight Piésold, 1998), there has been little or no review of the system at Wheal Jane since it became operational in 2000, and the most recent reports (i.e., URS, 2010; WYG, 2011) are centred around catchment characterisation studies. Thus, one of the initial tasks undertaken by the Authority was to review available historical data and reports.

In summary, the Authority found that whilst good records have been kept for the actual pumping and treatment activities at Wheal Jane, there are, in contrast, very limited data regarding regional groundwater and mine water levels and chemistry, patterns and trends. These data were primarily concerned with the rebounding mine water situation and some limited data post the 'outburst'. The data that exist were taken for specific studies and reports generally dated to the early-mid 1990s. It should be noted that although long-term and wider area monitoring has been suggested in the past (e.g., Knight Piésold, 1993; Knight Piésold, 1996), this recommendation was not taken up.

During the rebounding of mine water, some shaft samples were taken from the top few metres of water in various shafts in the area. The data from shaft sampling (Marcus Hodges Environmental Ltd, 1991) indicate the water at Mount Wellington and Wheal Jane have similar poor quality (i.e., Zn between 23 and $156 \mathrm{mg} / \mathrm{L}$ ). The shaft samples from some of the other mine shafts showed better-quality mine water (i.e., $\mathrm{Zn}$ between 2 and $55 \mathrm{mg} / \mathrm{L}$ ). Also evident was that water quality significantly improved in the monitored shafts as water levels rose. These data may indicate different sources or pathways for the mine water and/or some stratification of the mine water within the system. Reviewing the pumped quality data from Wheal Jane has also shown an improving situation over the past 20 years (as seen in Figure 4). These changes in water quality, along with changes in technologies since the 1990s, may allow for changes in the methods of mine water treatment. However, an assessment of such alternative technologies will be required prior to any proposed changes in treatment methods. 
In 2011, the Authority undertook an initial assessment of potential sites to include in a new regional mine water level monitoring network, and in 2012 a programme of regular monitoring of selected shafts was undertaken (Figure 5). These water level data allow the mine water levels and possible connections through to Wheal Jane to be assessed, which is achieved by observing findings, including mine water gradient and likely flow paths, any raised heads of water and changes in water levels across an area in response to pumping or rainfall. Recording and assessing these data gives the Authority a better understanding of how the surrounding area impacts any changes to pumping (i.e., wet weather events) or changes in chemistry, which could relate to changes in mine water flow paths or other such events.

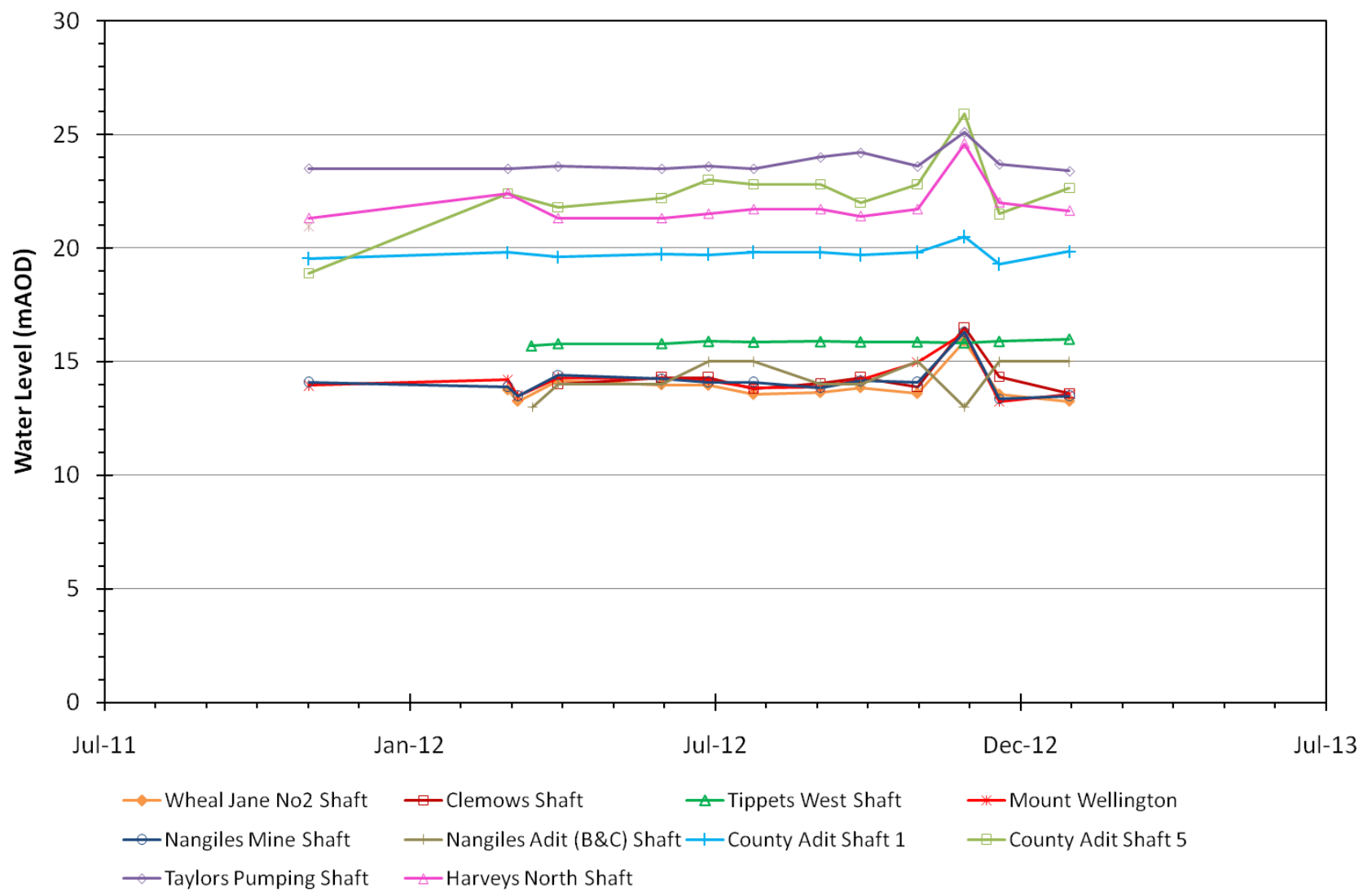

Figure 5 Mine water levels 2011 to 2013

Analysis of the water level, pumping and rainfall data has indicated that at Wheal Jane there are occasional wet weather events triggered by very high rainfall, resulting in high water levels and increased abstraction rates; historically, when the water levels have risen, the shaft pumps have been run at maximum capacity. On such previous occasions, the water levels at Wheal Jane have peaked at $16.8 \mathrm{mAOD}$ (March 2007), with a maximum abstraction rate of $475 \mathrm{~L} / \mathrm{s}$, and no uncontrolled discharges to the River Carnon have been observed from the adits. More recently, in November and December 2012 two closely spaces events occurred (Figure 6), and the water level peaked at approximately $16.5 \mathrm{mAOD}$. During these two recent events, emergency pumping was required to prevent uncontrolled discharges of polluted mine water, which included using additional temporary pumps installed in a nearby shaft. These additional pumping requirements gave a total emergency abstraction rate of approx $500-530 \mathrm{~L} / \mathrm{s}$. Note that although this rate is above the consented maximum daily abstraction rate of $440 \mathrm{~L} / \mathrm{s}$, the Environment Agency allowed dispensation for the temporary breach of the consent limits. Throughout the emergency pumping, the treated effluent from the scheme was within the water quality consents, thus alleviating any public concerns about potential environmental damage from uncontrolled discharges from Wheal Jane. 


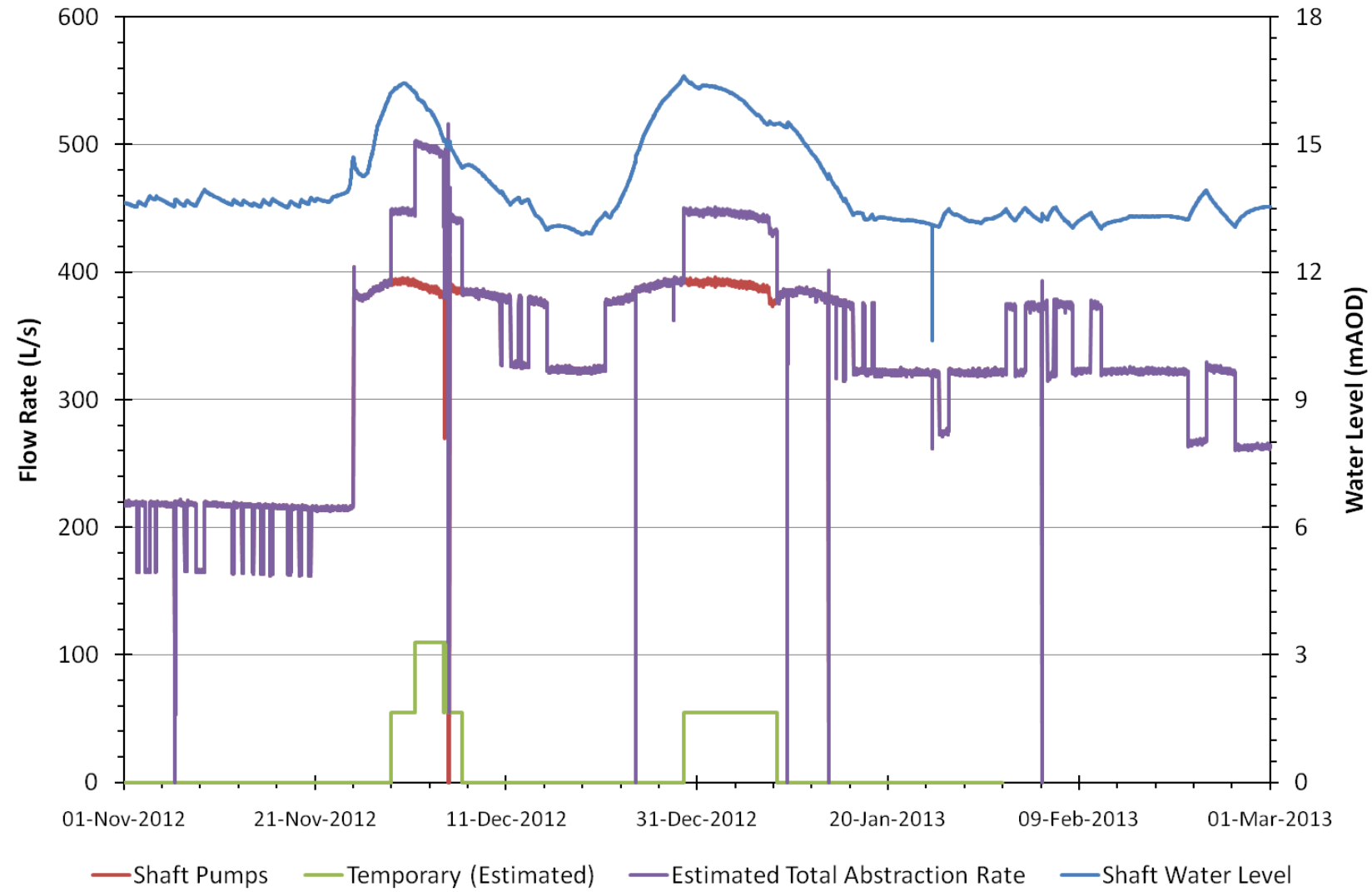

Figure 6 Wet weather events Winter 2012/13

Currently the exact hydraulic capacity and constraints of the scheme are uncertain. However, they are likely to be slightly above the $500 \mathrm{~L} / \mathrm{s}$ pumped, which is also above the design flow of $440 \mathrm{~L} / \mathrm{s}$. Hence, on these recent occasions the plant has exceeded expectations for treating very high flows. The emergency response was co-ordinated by multiple organisations and successfully managed the situation. However, the Authority is keen to compare the cost of the emergency response with the potential impacts that an overflow of a portion of the Wheal Jane mine water could cause. Impacts on the scale of the early 1990s appear unlikely, since metal concentrations are now much reduced (see Figure 4). Also, during wet weather events the Carnon is itself in spate and receives very high flows of County Adit mine water. Hence there may be a good argument that it would be more sustainable to allow some overflow from the Wheal Jane system during wet weather events.

In order to identify any vertical stratification of water quality in the pumping shaft, in April 2012 a camera survey and electrical conductivity/temperature survey were undertaken (Figure 7), with discrete samples taken throughout the shaft column at $50 \mathrm{~m}$ intervals; the shaft itself includes regularly spaced insets (c. $30 \mathrm{~m}$ ) to intercept the mine stope workings. The results from this survey indicate there is very little or no stratification within the sampled section of the shaft water column, with exceptions being a top section of 'cleaner' water (water is approx 5-10 m above the pumps) and a slight step around 195-200 mBGL, which coincides with an inset around levels 6-7 (based on the nearby Clemows Shaft Insets).

The results from the shaft sampling (undertaken at the same time as the survey) indicate the shaft water is the same as the pumped raw water, with iron concentrations around $110-115 \mathrm{mg} / \mathrm{L}$ and zinc concentrations varying between approximately $30 \mathrm{mg} / \mathrm{L}$ and $40 \mathrm{mg} / \mathrm{L}$. Any variations are likely to reflect slight changes in the mineralogical composition of the workings/strata, which could provide pollution in multiple sources for the input water. This new information assists in managing the plant by giving confidence that changing pumping rates is unlikely to significantly affect pumped water quality; if more pronounced stratification had been identified, then this could have indicated that increasing pumping would risk a deterioration in quality. 


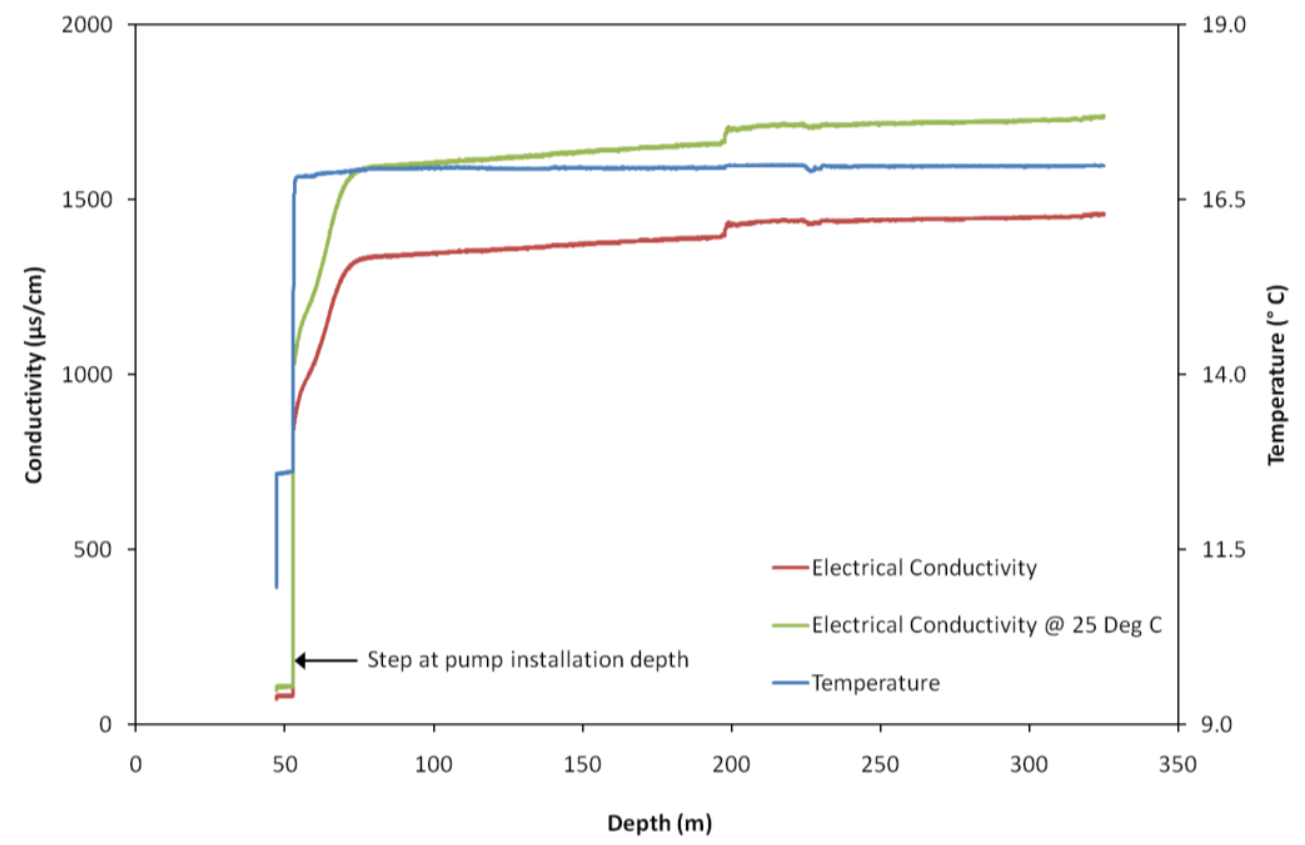

Figure 7 Temperature and electrical conductivity log of Wheal Jane No.2 shaft, April 2012

In terms of improving efficiency of the treatment plant itself, in 2012 the Authority also investigated the performance of a newly installed trial cascade (Figure 8) for degassing dissolved carbon dioxide from the raw mine water prior to treatment. From a report prepared for the Authority in 2011 (Siltbuster, 2011), a number of recommendations were made, where an efficiency saving of up to $20 \%$ on caustic dosing could be achieved by degassing of dissolved carbon dioxide. The recommendations included installation of a splash plate on the feed line into the pre-reactor; installation of a venturi on the mine water feed line; converting the potentially redundant pre-reactor to a degassing chamber if the plant is switched to a single stream process; and installation of a cascade. Following these recommendations, the decision was taken to trial a new cascade. This was installed on the mine water inlet of the Stream 1 pre-reactor tank to aid with the degassing of the mine water. As a result of this, the operations contractor reported a $7 \%$ savings in the lime usage in the plant.

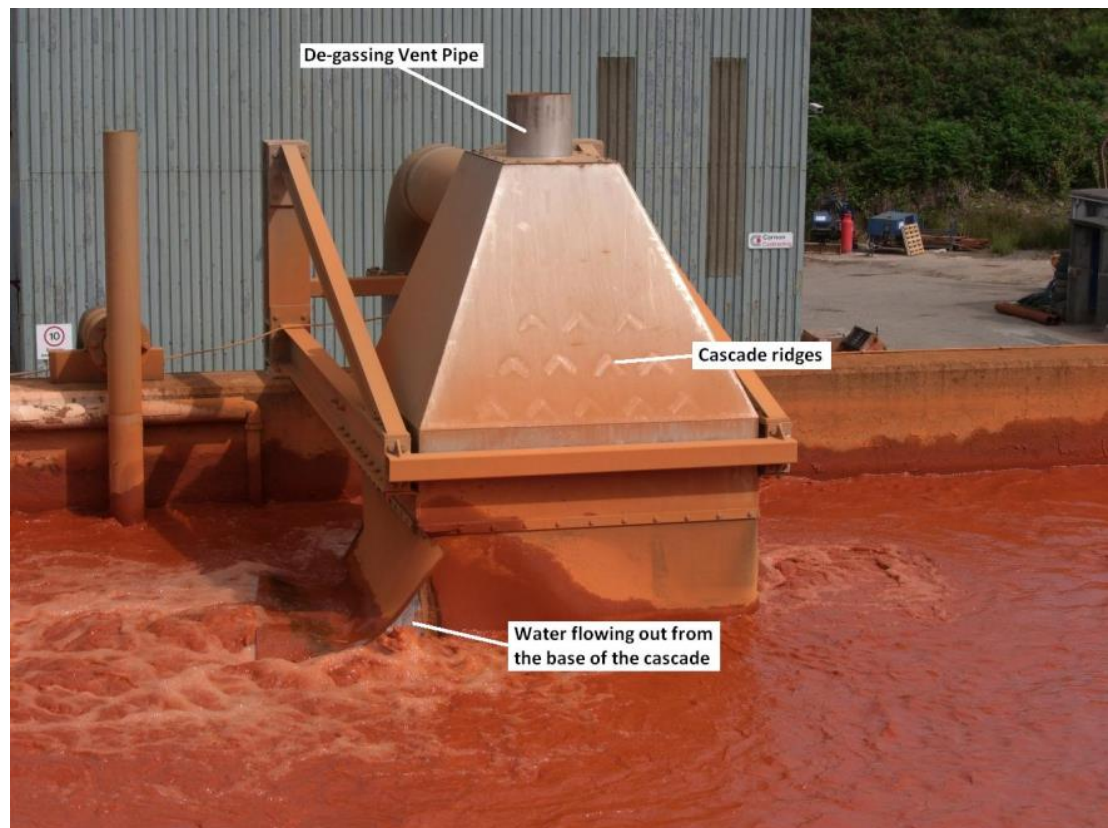

Figure 8 Degassing cascade, installed in 2012 (Coal Authority @ July 2012) 
By way of verification of this saving, in May 2012 the Authority undertook field testing of the alkalinity and acidity results of various stages of the scheme. The results showed a cold acidity $\left(\mathrm{as}^{\mathrm{CaCO}} \mathrm{C}_{3}\right.$ ) concentration of $307 \mathrm{mg} / \mathrm{L}$, of which $291 \mathrm{mg} / \mathrm{L}$ is total acidity (i.e., calculated from metals and $\mathrm{pH}$ ). The $16 \mathrm{mg} / \mathrm{L}$ difference represents the dissolved $\mathrm{CO}_{2}$, which could translate to an approximate saving of $5 \%$ if the dissolved $\mathrm{CO}_{2}$ is allowed to degas. The reported efficiency saving reported from installing the cascade of $7 \%$ seems to tie in well with these figures. This also suggests that the trial cascade has optimised the system with regard to degassing and that there are no significant benefits to investing in more-sophisticated degassing equipment.

\section{$5 \quad$ Forward strategy}

Although the Coal Authority has undertaken a number of appraisals and assessments of the various water levels, abstraction rates, mine water chemistry and treatment efficiencies, there are still a number of other possible scenarios that warrant further work and investigation. This further work should help the Authority to adapt and change the current pumping and treatment scheme in the long term to a more efficient, sustainable mine water management system. Improved conceptual understanding of the system and its risks are key to this. Some of the additional work and possible future scenarios that are to be investigated include:

- Determine the nature of any plugs and/or other restrictions affecting Wheal Jane and the neighbouring mines. In particular, the plug and valve on the Jane Adit should be tested to confirm its integrity and whether it could be used as part of a future controlled overflow system.

- Undertake a wider range of water level monitoring to aid assessment of potential risks of blockages in the system and any risks of blowouts and to identify any inflows in to the workings.

- Undertake shaft sampling across a regional spread of sites, which will allow a better understanding of any stratification in the mining blocks, along with aiding assessment of risks associated with any potential blowouts and/or surface discharge. This could also indicate any surface or near-surface inputs into the Wheal Jane system.

- Determine what the specific scenarios of allowing uncontrolled and/or controlled gravity discharges and identify any risks should a discharge occur.

- Develop a long-term strategy for any future pumping requirements at Wheal Jane. This should also be done in conjunction with assessing any future treatment options and or mine water control options.

- Develop an emergency strategy for dealing with high rainfall and other emergency events, in particular investigating further the idea of a controlled overflow.

- Better assess the benefit of degassing the mine water, with further samples to be taken from the raw mine water to assess in more detail the typical dissolved $\mathrm{CO} 2$ concentrations by direct analyses in preference to calculated concentrations.

- Undertake a study to assess the treatability of the mine water using a passive or semi-passive method for either all and/or part of the flow.

- Undertake a study to determine if the water at Wheal Jane can be treated passively or parttreated passively or if a significant flow can be treated passively.

- Assess any relevant alternative technologies as a possible future treatment option.

- Prior to undertaking any of these major changes to the pumping and treatment at Wheal Jane, particularly those referring to the controlled release of untreated mine water, a socio-political strategy should be developed to address any public concerns. 


\section{Conclusions}

Historically, prior to 2011, the main focus of the scheme at Wheal Jane was to prevent uncontrolled discharges of mine water by pumping and to treat the polluted mine water to meet the environmental discharge consents. This was achieved by the active (chemical) treatment plant built in 2000.

Since the 1990s, little or no mine water level or hydrogeochemical data have been collated or assessed for the area around Wheal Jane, although good records exist from Wheal Jane and the treatment plant itself. In addition, there was no review of any data or reassessment made between the plant becoming operational and 2011.

Since April 2011, the Coal Authority has undertaken a number of initial studies to further its knowledge and assist in any future work. These include regional mine water monitoring to assess the impacts on Wheal Jane from the connected mines and mine workings; shaft sampling and surveys to determine if there are any significant changes in mine water chemistry or stratification in the shaft and also to determine if there is any substantial amount of clean water at the top of the shaft (i.e., that likely to discharge first); an appraisal of high rainfall events and required quantities of water to be pumped; and an assessment of a degassing cascade to improve the chemical usage.

Since the pilot passive scheme was constructed and operated at Wheal Jane, the mine water chemistry has changed, with iron concentrations reduced from approximately $140 \mathrm{mg} / \mathrm{L}$ to $110 \mathrm{mg} / \mathrm{L}$ and zinc concentrations reducing from approximately $80 \mathrm{mg} / \mathrm{L}$ to $35 \mathrm{mg} / \mathrm{L}$. These changes and any further reductions in metals, along with any recent or novel changes in treatment technologies, could make future passive treatment a more viable option.

Ultimately, the Coal Authority envisages a scenario in which the water is not pumped and outflows are by gravity, and furthermore the water is treated by a passive, sustainable treatment scheme. However, this may be a very long-term outcome, and to achieve this, further studies and tests will need to be carried out.

\section{References}

Brown, M., Barley, B. and Wood, H. (2002) Minewater Treatment Technology, Application and Policy, IWA Publishing, 453 p. CL:AIRE (2004) Mine water treatment at Wheal Jane tin mine Cornwall, Case Study Bulletin (CSB4).

Coulton, R., Bullen, C., Dolan, J., Hallett, C., Wright, J. and Marsden, C. (2003) Wheal Jane mine water active treatment design construction and operation, Land Contamination \& Reclamation, Vol. 11(2), pp. 245-252.

Hallberg, K.B. and Johnson, D.B. (2003) Passive mine water treatment at the former Wheal Jane tin mine, Cornwall: important biogeochemical and microbiological lessons, Land Contamination \& Reclamation, Vol. 11(2), pp. 213-220.

Hamilton, R. (1993) The impact of discharges from Wheal Jane and abandoned tin mine on environmental water quality in south west England, in Congress Proceedings, 1st SETAC World Congress, Lisbon, Portugal, pp. 28-31.

Knight Piésold (1993) Wheal Jane Minewater Study Data Monitoring Review, Report for National Rivers Authority, 33 p.

Knight Piésold (WS Atkins) (1996) Historical Data Report - Wheal Jane Minewarter project Consultancy Studies 1996-1999, Report for Environment Agency, $53 \mathrm{p}$.

Knight Piésold (WS Atkins) (1998) Appraisal and Selection of the Long Term Treatment Option - Wheal Jane Minewarter Project Consultancy Studies 1996-1999, Report for Environment Agency, 104 p.

Marcus Hodges Environmental Ltd (1991) Wheal Jane Hydrogeological Impact Assessment - Assessment of Mine Drainage and Options for Mine Water Treatment, Report for National River Authority Southwest Region, $46 \mathrm{p}$.

Siltbuster (2011) Process Review Report in 2011 for the Wheal Jane Treatment Plant, Prepared for the Coal Authority, 29 p.

URS (2010) Wheal Maid Tailings Lagoon Further Assessment Actions under Part 2A of the Environmental Protection Act 1990 Seriousness of Pollution, Report for Environment Agency, 277 p.

Watermeyer, Legge, Piesold \& UhImann (1980) Final Report on the Investigation of Water Infiltration to the Mine, prepared for Carnon Consolidated Tin Mines Ltd. Wheal Jane Mine, 117 p.

Whitehead, P.G. and Prior, H. (2005) Bioremediation of acid mine drainage: an introduction to the Wheal Jane wetlands project, Science of the Total Environment, Vol. 338(1-2), pp. 15-21.

WYG (2011) Mine Water Pollution in the Carnon River Catchment 2009-2010, Project Carnon, Report for Environment Agency, $37 \mathrm{p}$.

Younger, P.L. (2000) The adoption and adaption of passive treatment technologies for the mine waters in the United Kingdom, Mine Water and the Environment, Vol. 19, pp. 84-97.

Younger, P.L. (2002) Mine water pollution from Kernow to Kwazulu-Natal: geochemical remedial options and their selection in practice, Geoscience in Southwest England, Vol. 10, pp. 255-266. 